УДК 314.74

Владислав ВОРОТНИКОВ

\title{
АКТУАЛЬНЫЕ ПРОБЛЕМЫ ДИАСПОРАЛЬНОЙ ПОЛИТИКИ СТРАН БАЛТИИ
}

\begin{abstract}
Аннотация. Статья посвящена рассмотрению современной политики государств Балтии в отношении своих диаспор. Несмотря на незначительную численность населения, зарубежные диаспоры выходцев из этих стран (в первую очередь титульных латышей, литовцев и эстонцев) многочисленны и продолжают оказывать влияние как на внутренние социально-экономические и политические процессы собственно в прибалтийских государствах, так и на политику стран пребывания (например, США). На основе компаративного анализа в статье рассматривается современное положение прибалтийских диаспор, а также цели и политическая практика государственной политики Латвии, Литвы и Эстонии по поддержанию контактов с диаспорами и репатриации. Последнее крайне актуально для стран Балтии в условиях негативных трендов демографической ситуации (не снижающихся темпов эмиграции, сокращения рождаемости, старения населения). Однако неолиберальная экономическая политика правительств, не создающая благоприятных условий для социальноэкономического развития и роста качества жизни населения, делает диаспоральную политику государств Балтии малоэффективной.
\end{abstract}

Ключевые слова: диаспоры, диаспоральная политика, страны Балтии, Прибалтика, Латвия, Литва, Эстония.

Страны Балтии (Латвия, Литва, Эстония) обладают небольшим населением (Латвия - 1934379 чел., Литва - 2799127 чел., Эстония - 1319133 чел.), которое, кроме того, за последние два с половиной десятилетия, т.е. с момента обретения ими независимости, сократилось, по данным официальной статистики, примерно на 20-25\% (на 1 января 1991 г. численность населения Латвии составляла 2658161 чел., Литвы - 3701968 чел., Эстонии - 1567749 чел.).

При существующей модели социально-экономического развития и миграционной модели (нетто-экспортеров рабочей силы) в этих странах в ближайшие не-

(C) Воротников Владислав Владиславович - кандидат исторических наук, ведущий научный сотрудник, Отдел исследований Центральной и Восточной Европы, Институт Европы РАН; доцент, кафедра истории и политики стран Европы и Америки, научный сотрудник, Центр европейских исследований Института международных исследований МГИМО МИД России. Adpec: Россия, 125009, Москва, ул. Моховая, д. 11, стр. 3. E-mail: vorotnikov.vladislav@gmail.com

Статья подготовлена при финансовой поддержке РФФИ в рамках проекта № 17-07-00016 "Россия и Центральная Европа: проблемы и перспективы взаимоотношений в условиях мирового политического кризиса”.

Современная Европа, 2018, № 7 
сколько десятилетий прогнозируется дальнейшее сокращение населения. По данным опубликованного в 2015 г. прогноза Европейской комиссии до 2060 г., к этому году население Литвы может сократиться еще на $38,1 \%$, Латвии - на 30,7\% (самые низкие показатели из всех 28 стран), Эстонии - на 17,2\% [The 2015 Ageing Report...: 22].

Несмотря на небольшую численность населения государств Балтии, сформировавшиеся в ходе нескольких волн эмиграции за прошедшие полтора века зарубежные диаспоры латышей, литовцев и эстонцев весьма многочисленны и представлены в разных уголках мира.

На сегодняшний день численность лиц литовского происхождения (как представителей традиционных исторических диаспор, так и уехавших в последние годы в качестве трудовых мигрантов), проживающих за рубежом, оценивается в 1,3 млн чел. (из них граждан современной Литвы, по официальным данным, более 300 тыс. чел.) [Globali Lietuva, 2016]; латвийского - 370 тыс. чел. [Diaspora Policy in Latvia, 2017] (схожими (неофициально) или меньшими (официально ок. 250 тыс. чел.) оценивается за последние годы численность мигрантов из Латвии); эстонского - от 120 до 200 тыс. чел. [Foreign Minister..., 2016] (кроме того, за постсоветские годы еще около 115 тыс. чел. официально зарегистрировали свой отъезд в качестве мигрантов). Наибольшие по численности общины (включая уехавших после 1991 г.) проживают:

1) литовцев - в США (720-750 тыс. чел.), в Великобритании (210 тыс.), в Ирландии (100-120 тыс.), в Бразилии (100-120 тыс.), в Канаде (60-65 тыс.), в Германии (40 тыс.), в Аргентине (30-40 тыс.), в России (30 - 50 тыс.), в Белоруссии (30 тыс.), в Норвегии (30-40 тыс.), в Латвии (25 тыс.), в Польше (25 тыс.), в Испании (15 тыс.), в Австралии (15 тыс.), на Украине (10 тыс.), в Уругвае (10 тыс.), в Швеции (8 тыс.), в Казахстане (7 тыс.), в Италии (5 тыс.), в Дании (5 тыс.);

2) латышей - в Великобритании (110 тыс.), в США (100-105 тыс.), в Ирландии (50 тыс.), в Швеции (30 тыс.), в Германии (30 тыс.), в Канаде (28 тыс.), в Австралии (25 тыс.), в Бразилии (25 тыс.), в России (20-25 тыс.), в Норвегии (11 тыс.), в Испании (7 тыс.), на Украине (5 тыс.).

3) эстонцев - в Финляндии (50-60 тыс.), в США (27 тыс.), в Канаде (25 тыс.), в Швеции (25 тыс.), в России (18 тыс.), в Великобритании (11 тыс.), в Австралии (8 тыс.), в Германии (6 тыс.), в Норвегии (5 тыс.).

Безусловно, рост численности иммигрантских сообществ латышей, литовцев и эстонцев в последние десятилетия не полностью равнозначен увеличению размеров диаспор. Хотя под диаспорой традиционно понимают «группу населения той или иной страны, принадлежащую по этническим и культурным характеристикам к другому государству», важнейшим признаком, отличающим ее от простой совокупности мигрантов, является «наличие стратегии взаимоотношений с государством проживания и исторической родиной (или ее символом); институтов и структур, деятельность которых направлена на сохранение и развитие этнической идентичности» [Боришполец, 2012]. Однако правительственная политика, ориентированная на 
поддержание контактов с уехавшими или на их возвращение, чаще всего рассматривает диаспору максимально широко, включая в нее не только тех, кто стремится сознательно сохранять свою идентичность и связь со страной происхождения, но всех, кто, как уже было отмечено, имеет с ней этническую или культурную (язык, религия, символ исторической родины) связь.

По объективным причинам (с одной стороны, депопуляция, старение населения, снижение качества человеческого капитала; с другой стороны, значительные объемы денежных трансфертов от мигрантов) за последние годы в государствах Балтии вырос интерес к исследованию диаспор и изучению возможностей вовлечения их представителей в политическую, экономическую и культурную жизнь своих стран. Работают специализированные исследовательские центры - Центр исследований диаспоры и миграции Латвийского университета (Рига), Институт литовской эмиграции при Университете Витовта Великого (Каунас, Литва), Центр исследований диаспоры и миграции Тартуского университета (Эстония). Современное положение диаспор все чаще становится предметом научных исследований [Муксинов, 2012; Garoza, 2017, 2018; Gudelis, Klimavičiūtè, 2016; Kḷave, Šūpule, 2015; Krapāne, 2016; Tammaru, Kumer-Haukanõmm, Anniste, 2010]; кроме того, с начала 2010-х гг. проводятся регулярные социологические исследования их структуры и потребностей.

Вместе с тем диаспоральная политика каждой из трех стран имеет свою специфику.

\section{Литва}

Из трех стран Балтии Литва реализует наиболее системную политику в отношении своей диаспоры. Как уже отмечалось, численность литовской диаспоры на сегодняшний день оценивается примерно в 1,3 млн чел. (с учетом уехавших без регистрации отъезда, по всей вероятности, даже больше), т.е. составляет более $40 \%$ от всего населения Литвы. Как заявила заместитель министра иностранных дел А.Скайсгарите-Ляушкиене в 2010 г., «Литва превратилась в диаспорное государство» [Globali Lietuva..., 2010].

С начала 2000-х гг. руководство Литвы начало системную работу по выработке политики в отношении диаспоры и проблем, возникающих в результате массовой миграции населения. В этой связи в разные годы были приняты «Долгосрочная стратегия развития государства» (2002), где впервые были подняты вопросы, связанные с миграцией, «Национальная стратегия демографической политики» (2004), «Стратегия по регулированию экономической миграции» (2007), «Основополагающие принципы иммиграционной политики Литвы» (2008), действующая и по сей день Программа по обеспечению литовских политзаключенных и ссыльных [Politiniu kalinių..., 2014], Программа сотрудничества с зарубежными литовскими общинами (на 2009-2012 гг.). Кроме того, в 2009 г. Институтом социальных исследований совместно с международными организациями по миграции и Европейской миграционной сетью было проведено исследование по теме «Возвратная миграция: теоретические прогнозы и ситуация в Литве» [Муксинов, 2012: 102]. 
В 2011 г. все это увенчалось запуском программы «Глобальная Литва (2011 2019 гг.)», при создании которой авторы пытались интегрировать опыт других стран, которые имеют значительную историю общения со своими крупными зарубежными диаспорами (Польша, Ирландия, Израиль, Индия). Программа «Глобальная Литва» рассматривает диаспору «как проживающую за границей часть литовской нации, которую составляют как граждане Литовской Республики и лица литовского происхождения, так и лица нелитовцы, происходящие из Литвы, связывающие себя с Литвой историческими, культурными, социальными, экономическими или политическими связями». Программа формулирует следующие основные цели:

1) стремиться к тому, чтобы в условиях глобализации зарубежные литовцы сохранили свою национальную идентичность; заботиться о людях, принадлежащих к литовскому национальному меньшинству за границей, охранять их права;

2) поощрять зарубежных литовцев к включению в политическую, экономическую, научную, культурную и спортивную жизнь Литвы;

3) укреплять связи литовцев зарубежья с Литвой и таким образом содействовать их возвращению на родину; утечку мозгов обратить в процесс обмена мозгами;

4) используя возможности современных технологий, в том числе информационных, создать коммуникационное пространство, объединяющее литовцев Литвы и зарубежья и отвечающее их информационным, социальным, культурным и прочим потребностям;

5) поощрять диаспору Литвы к распространению в мире информации о Литве [„Globalios Lietuvos“..., 2010].

Программа реализуется 13 министерствами и государственными учреждениями при содействии различных НПО и зарубежных общин, при этом координирующая роль принадлежит МИД Литвы. Она не имеет единого источника финансирования средства на реализацию тех или иных проектов выделяются каждым ведомством. В соответствии с планом действий на 2016-2018 гг. на реализацию программы ежегодно тратилось не менее 3,4 млн евро. К примеру, МИД каждый год поддерживает около 100 проектов (сумма финансирования - от 300 до 5000 евро).

Имея развитую систему национальных общин, объединенных во Всемирную общину литовцев (официально зарегистрированные общины имеются в 41 стране; ВОЛ имеет собственную конституцию, не реже 1 раза в три года проводит заседания сейма; издается журнал «Pasaulio lietuvis» («Литовец мира»)) и во Всемирный союз литовской молодежи, Литве тем не менее не удается полностью реализовать цели программы. Проведение международных мероприятий (к примеру, Всемирных экономических форумов литовцев, Всемирных спортивных игр литовцев и др.), расширение доступности международного телевидения Литвы (LRT Lituanica) и создание сетевых сообществ (как в буквальном - страница и поддержание страницы программы «Глобальная Литва» в Facebook, так и в расширительном смысле «Global Lithuanian Leaders») не решает ключевой проблемы - возвращения уехавших в последние годы литовцев обратно. 
Основными причинами нежелания возвращаться представители диаспоры обычно называют сложные экономические условия, низкий уровень заработной платы и отсутствие возможностей трудоустройства, недоверие к политической системе, ее неэффективность и коррупцию и т.д. При этом опросы, ежегодно проводимые по заказу МИД Литвы, в целом отражают лишь точку зрения наиболее активной части литовской диаспоры; остальные же в целом не вовлечены или безразличны к деятельности литовских общин. К примеру, по данным опроса, проведенного в 2017 г., 91\% респондентов заявили, что следят за событиями, происходящими в Литве, однако только 55\% отметили, что «не исключают возможности когда-нибудь вернуться в Литву», тогда как «31\% опрошенных возвращаться не планируют» [Užsienio..., 2017]. Характерен и другой пример. В тексте программы «Глобальная Литва» отмечалась необходимость «ввести систему интернет-голосования» для повышения активности избирателей за рубежом (в 2004 г. проголосовали только около 17 тыс. чел., в 2008 г. - 10 тыс. чел., а в 2009 г. - 15 тыс. чел.). Однако система не создана и по сей день, а последующие выборы не показали увеличения интереса к голосованию среди эмигрантов: в 2012 г. - 10,4 тыс. чел., в 2014 г. - 14,7 тыс. чел., в 2016 г. - 17 тыс. чел.

Наконец, еще один сюжет, который не был включен в программу «Глобальная Литва», но, как показывают опросы среди представителей диаспор, мог бы увеличить интерес представителей экономических мигрантов последних лет к возвращению на родину (так полагали 68\% опрошенных в 2009 г.), - это введение двойного гражданства для уехавших после 1990 г. По нынешнему законодательству двойное гражданство может предоставляться только тем (а также их потомкам), кто уехал либо был выслан с территории Литвы до 1990 г. Вопрос о проведении референдума по проблеме двойного гражданства многие годы вызывал активную дискуссию в литовском политическом истеблишменте. По всей видимости, тема поддержки и репатриации уехавших в последние годы литовцев станет значимой в ходе предстоящих президентских выборов 2019 г., а сам референдум наконец-таки состоится в те же дни.

\begin{abstract}
Латвия
Латвийское правительство реализует миграционную политику, практическая составляющая которой направлена «на поддержку тех граждан Латвии и их семей, которые проживают за рубежом, рассматривают возможность или уже решили вернуться и работать в Латвии, а также которые хотят основать собственный бизнес или развивать бизнес-сети в Латвии» [Coping with Emigration..., 2013]. При этом, в отличие от Литвы, принятые в 2013 г. поправки к Закону о гражданстве Латвии разрешили этническим латышам и ливам, проживающим в государствах ЕС, НАТО, EACT, а также в Австралии, Бразилии и Новой Зеландии и владеющим латышским языком, чьи предки ранее жили на территории Латвии, иметь двойное гражданство.

Как уже было отмечено, по официальным оценкам, латвийская диаспора составляет примерно 370 тыс. чел., при этом латвийское государство подходит к опре-
\end{abstract}


делению понятия «диаспора» расширительно, включая в него всех уехавших как в XIX и XX вв., так и в течение последних десятилетий, как граждан, так и неграждан (ieklaujot visus Latvijas valstspiederīgos - gan pilsoņus, gan nepilsoņus) [Rīcības plāns..., 2014]. Институционально актив всемирной латвийской диаспоры объединен во Всемирную ассоциацию свободных латышей (World Federation of Free Latvians), наиболее активной и многочисленной (если говорить о «старых» диаспорах) составляющей которой является Американская латвийская ассоциация (American Latvian Association).

Выход вопросов, связанных с ухудшением демографической ситуации в Латвии (в том числе в связи с ростом эмиграции), в приоритеты государственной политики относится к периоду президентства А. Берзиньша (с 2008 г. эта тема стала обсуждаться на государственном уровне). С апреля 2011 г. в Сейме стала работать специальная подкомиссия по вопросам демографии, а в октябре 2013 г. в рамках Наблюдательного совета по реализации основных принципов политики национальной идентичности, формирования гражданского общества и интеграции была создана межведомственная Рабочая группа по диаспоральной политике.

Результатом работы группы стало возникновение системной политики латвийского государства в отношении латвийской диаспоры. В 2014 г. был опубликован «План действий. О сотрудничестве с латвийской диаспорой в 2015-2017 гг.». Кроме того, были приняты еще два документа стратегического планирования, в которых обозначались ключевые направления сотрудничества с диаспорой, - «План действий по поддержке реэмиграции на 2013-2016 гг.» (на эти цели было выделено 1,5 млн евро) и «Основные принципы политики интеграции, формирования гражданского общества и идентичности на 2014-2018 гг.».

Недавно проведенное исследование диаспоры, в котором приняло участие более 14 тыс. респондентов из 118 стран, показывает, что большинство эмигрантов не собираются возвращаться в Латвию в ближайшем будущем из-за существующих экономических и социальных условий: $27 \%$ не планируют возвращаться, $41 \%$ могли бы вернуться при определенных условиях, 16\% планируют возвращаться в течение 5 лет, а еще $16 \%$ - после выхода на пенсию. В качестве препятствий для возвращения на родину респонденты отмечали отсутствие приемлемых возможностей для трудоустройства (73\%), социальной поддержки (72\%), профессионального роста и организации бизнеса (63\%), разочарованность латвийским государством (58\%) [Kḷave, Šūpule, 2015: 202], причем 75\% уехавших после 2000 г. оценили экономическую ситуацию и государственную политику как плохую, 18\% полагают, что она улучшается, 92\% недовольны работой правительства. Хотя большинство респондентов $(63 \%)$ чувствуют свою связь с Латвией и $67 \%$ следят за новостями, только $25 \%$ подписаны на онлайн-группы диаспоры или на рассылку. Наконец, $82 \%$ опрошенных полагают, что государство не заинтересовано в них [Krapāne, 2016]. Причем только $9 \%$ знают о государственной политике в области поддержки реэмиграции, в то время как 61\% вообще не слышали о ней [Kḷave, Šūpule, 2015: 202]. 


\section{Эстония}

Эстонская политика в отношении диаспоры реализуется в соответствии с документом «Программа соотечественников 2014-2020» («Rahvuskaaslaste programm 2014-2020»), которая продолжает аналогичные программы 2004-2008 и 2009-2013 гг. Культурная составляющая диаспоральной политики обозначена также в документах «Программа развития эстонского языка на 2011-2017 годы» и «Основы политики в области культуры до 2020 года». За работу в области миграционных процессов отвечает Фонд интеграции (до 2017 г. - Фонд интеграции и миграции «Наши люди» (MISA, «Meie Inimesed SA»)), учредителем которого является министерство культуры Эстонии. Фонд «консультирует по миграционным вопросам лиц, переезжающих на постоянное жительство в Эстонию, и этнических эстонцеврепатриантов. Помимо консультирования он оказывает репатриантам при необходимости также финансовую поддержку».

В целом вопрос осуществления комплексной, централизованной политики в Эстонии в отношении диаспоры стоит наименее остро. Причин тому две. Во-первых, сокращение населения Эстонии и масштабы эмиграции значительны, однако не носят таких угрожающих темпов, как в Латвии и Литве. Во-вторых, отличием эстонской миграционной модели является также и то, что ввиду близости страны назначения миграция (сегодня в Финляндию отправляется не менее 75-80\% мигрантов) чаще носит временный (иногда сезонный) характер. Более того, многие эстонцы, имея основную работу в Таллине, на выходных подрабатывают в Финляндии (паром до Хельсинки идет два с половиной часа); конкретная статистика, подтверждающая данное явление, отсутствует, однако это является общеизвестным фактом.

С 2000 г. Фонд интеграции реализует программу финансовой поддержки реэмигрантов (return support), в рамках которой ежегодно нескольким десяткам возвращающимся на родину эстонцам (кто не жил в Эстонии более десяти лет или родился за пределами Эстонии) предоставляется финансовая помощь в размере до 2000 евро на человека для обустройства на новом месте жительства (relocation support) (см. табл. 1).

Таблица 1

Выплата пособий Фондом интеграции и миграции (MISA) возвращающимся в Эстонию в 2011-2015 гг.

\begin{tabular}{|c|c|c|c|c|c|}
\hline Год & $\mathbf{2 0 1 1}$ & $\mathbf{2 0 1 2}$ & $\mathbf{2 0 1 3}$ & $\mathbf{2 0 1 4}$ & $\mathbf{2 0 1 5}$ \\
\hline $\begin{array}{c}\text { Количество } \\
\text { человек }\end{array}$ & 61 & 91 & 97 & 70 & 122 \\
\hline $\begin{array}{c}\text { Общая } \\
\text { сумма (€) }\end{array}$ & 55070 & 70477 & 74835 & 63910 & 79258 \\
\hline
\end{tabular}




\begin{tabular}{|c|c|c|c|c|c|}
\hline $\begin{array}{c}\text { Средняя сумма } \\
(€)\end{array}$ & 902 & 774 & 771 & 913 & 649 \\
\hline
\end{tabular}

Источник. Фонд интеграции Эстонии.

Кроме того, в 2010-2012 гг. действовала программа «Таланты - домой!», которая была ориентирована на получающих за границей высшее образование молодых людей (целевая аудитория была оценена в 4000-4500 чел.). Результатом программы стала поддержка возвращения всего 27 человек (при 743 желающих).

В целом диаспоральная политика в Эстонии, ориентированная, собственно, на эстонских граждан, носит достаточно ограниченный характер. Однако она имеет и другое, политическое измерение, связанное с поддержкой Эстонией развития финно-угорских народов на территории Российской Федерации.

\section{Прибалтийские диаспоры в России}

В последние десятилетия диаспоры стран Балтии стало принято подразделять не только по географическому принципу на «западную» и «восточную», но также и по хронологическому - в соответствии с периодом ее создания (или расширения численности) - на диаспору, сформировавшуюся до 1990-1991 гг. и после. Диаспоры в России обычно рассматриваются в рамках первой дихотомии, поскольку, будучи и так немногочисленными, с 1950-х гг. они стремительно сокращаются (см. Табл. 2).

Таблица 2

Численность латышей, литовцев и эстонцев в РСФСР/РФ (чел.)

\begin{tabular}{|l|l|l|l|l|l|l|}
\hline \multicolumn{1}{|c|}{ Год } & $\mathbf{1 9 5 9}$ & $\mathbf{1 9 7 0}$ & $\mathbf{1 9 7 9}$ & $\mathbf{1 9 8 9}$ & $\mathbf{2 0 0 2}$ & $\mathbf{2 0 1 0}$ \\
\hline Латыши & 74932 & 59695 & 67267 & 46829 & 28520 & 18979 \\
\hline Литовцы & 108579 & 76718 & 66783 & 40427 & 45569 & 31377 \\
\hline Эстонцы & 78566 & 62980 & 55539 & 46390 & 28113 & 17875 \\
\hline
\end{tabular}

Источник. Данные переписей населения.

Политика Латвии и Литвы в отношении своей диаспоры, проживающей на территории Российской Федерации, в основном не выходит из общих рамок диаспоральной политики, в то же время эстонская диаспоральная политика в России приобрела с конца 1990-х гг. особую - угро-финскую - составляющую.

Прибалтийские диаспоры в России формировались в несколько этапов. До Первой мировой войны происходила стихийная миграция преимущественно в Петербург, Псков и Новгород; кроме того, в связи со столыпинскими реформами увеличился поток мигрантов в Сибирь. Окончание Первой мировой войны и провозглашение государственной независимости стран Балтии вызвали первую крупную волну репатриации. Второй этап - увеличение численности латышей, литовцев и эстонцев на территории России в ходе пред- и послевоенных депортаций. С нача-

Современная Европа, 2018, № 7 
лом «оттепели» начинается последовательное уменьшение их численности. На это, среди прочих причин, повлияло как возвращение на историческую родину, так и ассимиляция с представителями других этносов. На сегодняшний день в России действует ряд организаций, созданных представителями прибалтийских диаспор.

Так, латышские культурные общества возникли в крупных городах России Москве, Санкт-Петербурге, Омске, Томске, Красноярске, Магадане, Смоленске, Пскове. Существуют также региональные сообщества (Латышский культурный центр Башкортостана; объединение «Коми-Балтия», включающее латышские кружки из Сыктывкара, Инты и Ухты). Кроме того, в Москве, Санкт-Петербурге, Башкортостане, Магадане и в поселке Нижний Булан Красноярского края стали действовать латышские евангелическо-лютеранские приходы, а в селе Бобровка Омской области - приход баптистов. Все латышские центры объединены в одну организацию - Съезд российских латышей, которая входит в состав Всемирной ассоциации свободных латышей ${ }^{1}$.

Наиболее крупные сообщества литовцев сконцентрированы сейчас в Калининградской области, Москве и Московской области, Санкт-Петербурге, Красноярском и Краснодарском краях, Иркутской, Тюменской областях, Коми, Карелии. В России действует не менее 30 различных литовских организаций. Еще в «Программе сотрудничества с зарубежными общинами литовцев на 2009-2012 годы» было упомянуто о том, что в «специфических регионах» (т.е. в России, Белоруссии, Польше) «необходимо усилить политическую поддержку соотечественников со стороны Литвы, чтобы эти страны гарантировали прежде всего сохранение литовской системы просвещения» [Муксинов, 2012: 60]. Издается ряд печатных изданий - газета «Литовец Петербурга», «Новая заря» (г. Калининград), «Земля Донелайтиса» (издается в Вильнюсе для распространения в среде диаспоры). С 2006 г. Советом молодежных организаций Литвы реализуется проект «Миссия Сибирь» (приостановлен в 2018 г.), в ходе которого молодые литовцы посещают места ссылок и заключения литовцев, встречаются с проживающими там представителями литовских общин.

Спецификой литовской диаспоральной политики в Российской Федерации является наличие регулярно обновляемых планов по поддержке возвращения литовских политзаключенных и ссыльных, а также членов их семей в Литву. Как отмечает Р.И. Муксинов, «основная масса ссыльных и политзаключенных вернулась в Литву в 1956-1959 годах. Среди них немало тех, кто негативно относится к русским и России. «Возвращающиеся в Литву после провозглашения независимости в 1990 году относятся к России и россиянам гораздо лучше и даже просто хорошо», заметил нам в интервью сын одного из ссыльных литовцев. Он же особо подчеркнул: «Мы выжили в Сибири только потому, что нам помогали простые русские люди». Благодаря современным исследованиям выяснилось одно очень важное обстоятельство: не Москва, а Вильнюс в лице А. Снечкуса длительное время препятствовал возвращению ссыльных на родину. Причина тому - боязнь серьезных

1 Латышская община в России (2018). Посольство Латвии в России. 06.07.2018. URL: http://www.mfa.gov.lv/ru/moscow/latyshskaya-obshchina-v-rossii (дата обращения: 16.12.2018).

Современная Европа, 2018, № 7 
столкновений, возможных в связи с тем, что дома, квартиры и земли ссыльных уже были заняты другими людьми» [Муксинов, 2012: 138].

Программа возвращения политзаключенных и ссыльных действует с 1992 г.; всего за это время в Литву выразили желание вернуться более 2,5 тысячи семей (не только из России, но и из других государств постсоветского пространства), из которых на момент окончания действия предыдущей программы (2013 г.) жильем было обеспечено 1930 семей, финансовую поддержку получило более 4000 чел. В 1992-2013 гг. на строительство/покупку жилья для переселенцев было потрачено 106,7 млн литов (30,9 млн евро), на реализацию программы в 2015-2017 гг. из государственного бюджета было запланировано выделить 1,96 млн евро [Politinių kalinių..., 2014].

Наконец, самые значительные эстонские диаспоры проживают сегодня в Красноярском крае, Омске, Санкт-Петербурге и Москве. Небольшие общины есть в Новосибирской, Томской, Омской, Тверской и Псковской областях, на Кавказе (самое известное поселение - «Эсто-садок») и в Крыму. Кроме того, 200-300 чел. представителей народности сету проживают в пограничных с Эстонией районах. Как отмечается эстонским внешнеполитическим ведомством, «общины делятся по времени их возникновения и составу. К примеру, московская эстонская община почти полностью состоит из новых эмигрантов (эмигранты 1950 - 2000-х гг. и их потомки), тогда как диаспору Петербурга в основном составляют потомки эмигрантов XIX и начала XX в. Среди живущих в деревнях Красноярского края, Тверской и Томской областей эстонцев и сету новых эмигрантов почти нет» ${ }^{1}$. В 1990-е гг. в самых больших общинах были созданы свои культурные общества (в Санкт-Петербурге, Москве, Архангельске, Твери, Красноярском крае, Череповце, Петрозаводске). С 1994 г. в Москве вновь действует евангелический лютеранский приход Святого Иоанна [Tammaru, 2010]. Наиболее известное эстонское общественное объединение Санкт-Петербургское эстонское общество культуры «Эстония». Кроме того, в Санкт-Петербурге действуют эстонская евангелическо-лютеранская община Святого Иоанна, эстонский евангелическо-лютеранский приход Святого Иоанна, приход русско-эстонской Свято-Исидоровской церкви Санкт-Петербургской епархии. Вновь стала издаваться газета «Петербургские ведомости» («Peterburi Teataja»), ocнованная в 1908 г.

Как уже было отмечено, особая составляющая диаспоральной политики Эстонии - патернализм в отношении финно-угорских народов. Причем характерно, что на практике ориентирована эта политика в основном на российских финно-угров (помимо собственно эстонцев и финнов, это карелы, вепсы, ижорцы, водь, мордва, марийцы, удмурты, ханты, манси, коми и др.), хотя представители этих народов как национальное меньшинство проживают еще в Норвегии, Швеции и Финляндии (саамы), Латвии (ливы), Румынии, Словакии, Сербии и на Украине (венгры) и др. Документально эта политика отражена в «Программе родственных народов Эсто-

1 Эстонцы в России / Посольство Эстонии в России. URL: http://www.estemb.ru/estonia_i_rossija/estontsi.

Современная Европа, 2018, № 7 
нии» [Программа..., 2010)], реализация которой осуществляется через воссозданную в 1991 г. (ранее действовала в буржуазной Эстонии с 1927 г.) некоммерческую организацию «Фенно-Угрия», координирующую сотрудничество с родственными финно-угорскими народами и осуществляющую финансирование как научнообразовательных, так и культурных проектов на территории Эстонии и в самой России. В парламенте Эстонии действует «группа поддержки финно-угорских народов».

Интерес к развитию финно-угорских народов в России нередко приобретает конфронтационно-политическую окраску в ряде документов и заявлений (в частности, нашумевшие заявления эстонского президента Тоомаса Хендрика Ильвеса в 2008 г. на пятом конгрессе финно-угорских народов в Ханты-Мансийске и в сентябре 2014 г. о том, что «строительство порта в Усть-Луге противоречит декларации ООН о правах коренных народов» 2015 г.; доклад «Положение финно-угорских и самодийских народов», подготовленный в 2006 г. членом эстонской делегации в ПАСЕ Катрин Сакс, по итогам которого была принята рекомендация ПАСЕ № 1775 «О положении финно-угорских и самодийских народов» [Чечевишников, 2010]), в которых заявлялось о якобы ухудшении/угрожающем положении для финноугорских народов и их культурно-языковой самобытности в России. Эта же озабоченность отражена на интернет-сайтах как общества «Фенно-Угрия», так и посольства Эстонии.

В силу специфики исторического развития страны Балтии обладают весьма обширной по численности диаспорой в разных странах мира, в том числе в США. В последние годы это позволяло им, к примеру, активно привлекать внимание американского политического истеблишмента ${ }^{1}$ к проблематике безопасности в регионе Балтийского моря проведением крупных международных конференций, которые получали соответствующее информационное сопровождение в интересах реализации целей американской внешней политики, и эффективно лоббировать решения, связанные с реализацией проекта поставок сжиженного природного газа в регион, а также с усилением военного присутствия США и НАТО в регионе Восточной Балтики и т.д. [Krapāne, 2016; Garoza, 2017, 2018].

Угроза депопуляции требует от политического руководства стран Балтии разработки и проведения целенаправленной политики по сокращению эмиграции и возвращению рабочей силы. На сегодняшний день Литве и Латвии удалось разработать и начать реализовывать подобные программы. Вместе с тем как литовская программа «Глобальная Литва», так и латвийская политика в отношении диаспоры носят скорее стратегический и долгосрочный характер и на сегодняшний день не очень успешны с точки зрения решения основной задачи - репатриации эмигрантов. Причины этого состоят, во-первых, в том, что соответствующие диаспоры не-

\footnotetext{
${ }^{1}$ К примеру, созданный в 1997 г. так называемый Балтийский кокус сегодня включает 74 конгрессмена от Демократической и Республиканской партий.
} 
достаточно консолидированы, подавляющее большинство мигрантов последней волны не участвуют в жизни заграничных общин, недостаточно информированы о возможностях такого участия и не слишком заинтересованы в нем, а во-вторых, в том, что экономическое положение и общий курс экономического развития этих государств демонстрируют реальную невозможность создать необходимые социально-экономические условия и обеспечить адаптацию потенциальных реэмигрантов. Около трети уехавших вообще не собираются возвращаться назад, еще столько же не планируют делать это в ближайшие пять лет (причем в латвийском случае из числа уехавших нелатышей не планируют возвращаться даже больше - до 60-70\%). Объемы денежных переводов от эмигрантов в посылающую страну также пока являются значительными (для Латвии они оценивается в 2\% ВВП, для Литвы - в 5\%, для Эстонии - в 3\%) [Coping with Emigration..., 2013: 19], однако будут снижаться в средне- и долгосрочной перспективе, поскольку связи с родиной в течение 5-10 лет после отъезда начинают ослабевать.

Практика диаспоральной политики стран Балтии показывает, что они в целом смирились со сложившейся ситуацией. Поэтому сегодня эта политика ориентирована, скорее, не на возвращение эмигрантов, а на сохранение их национальной идентичности, на максимальное вовлечение в деятельность сетевых общественных объединений, а значит, в том числе и на использование диаспоры как ресурса влияния, лоббистской силы (в особенности в ведущих странах Запада).

\section{Список литературы}

Боришполец К.П. (2012). Механизмы взаимодействия государства с национальными диаспорами. Ежегодник ИМИ. № 1(2). С. 79-86.

Муксинов Р.И. (2012). Политика властей Литвы в отношении своей зарубежной диаспоры. Вильнюс: Politika.

Программа родственных народов Эстонии (2010). Сайт НДО «Учреждение Фенно-Угрия». URL: http://jabadaba.eki.ee/public/buklet-hp.pdf (дата обращения: 16.12.2018).

Чечевишников А.Л. (2010). Положение финно-угорских народов России: внутриполитический и международный аспекты. Ежегодник ИМИ. С. 448-455.

\section{References}

Borishpoletz K.P. (2012). Mexanizmy vzaimodejstviya gosudarstva s nacional'nymi diasporami [Mechanisms of state interaction with national diasporas]. Ezhegodnik IMI [Yearbook of Institute of International Studies]. № 1(2). S. 79-86.

Chechevishnikov A.L. (2010). Polozhenie finno-ugorskih narodov Rossii: vnutripoliticheskij i mezhdunarodnyj aspekty [The state of the Finno-Ugric peoples of Russia: domestic political and international aspects]. Ezhegodnik IMI [Yearbook of Institute of International Studies]. S.448-455.

Coping with Emigration in Baltic and East European Countries (2013). OECD Publishing, 2013.

Diaspora Policy in Latvia (2017). Ministry of Foreign Affairs of the Republic of Latvia. 06.07.2017. URL: http://www.mfa.gov.lv/en/policy/2014-12-22-11-41-00/diaspora-policy-in-latvia

Foreign Minister Marina Kaljurand's message to Estonian expatriates on the occasion of $25^{\text {th }}$ Anniversary of the Restoration of Independence of Estonia (2016). Ministry of Foreign Affairs. August 22, 2016. URL: $\quad$ https://vm.ee/en/news/foreign-minister-marina-kaljurands-video-message-estonian-expatriatesoccasion-25th-anniversary (accessed on 16.12.2018).

Garoza I. (2017). The role of diaspora in the framework of Latvian foreign and security policy. Latvian Foreign and Security Policy Yearbook 2017. Pp. 224-238. 
Garoza I. (2018). The role of Latvian diaspora within the framework of foreign policy action planning. Latvian Foreign and Security Policy Yearbook 2018. Pp. 231-245.

Globali Lietuva (2016). [Global Lithuania]. URL: https://www.urm.lt/default/lt/globali-lietuva (accessed on 16.12.2018).

Globali Lietuva: kapituliacija ar tikrovè (2010). [Global Lithuania: surrender or reality]. Portalas „Lietuva 2030”. 2010.12.15. URL: https://www.lietuva2030.1t/lt/naujienos/443-globali-lietuva-kapituliacijaar-tikrove (accessed on 16.12.2018).

Gudelis D., Klimavičiūtė L. (2016). Assessing "Global Lithuania": the strengths and weaknesses of Lithuanian diaspora engagement strategy. Journal of Baltic Studies, Volume 47, Issue 3. Pp. 325-348.

Krapāne A. (2016). Latvia's Cooperation with Diaspora in 2015. Latvian Foreign and Security Policy Yearbook 2016. Pp.107-116.

Muksinov R.I. (2012). Politika vlastej Litvy v otnoshenii svoej zarubezhnoj diaspory [The policy of the Lithuanian authorities regarding their overseas diaspora]. Vilnius: Politika.

Politinių kalinių ir tremtinių bei jų šeimų narių sugrịžimo ị Lietuvą 2015-2017 metų veiksmų planas (2014). [Action Plan for returning political prisoners and deportees and their families to Lithuania for 20152017]. URL: https://www.e-tar.lt/portal/legalAct.html?documentId=d9011f00a52111e3aeb49a67165e3ad3 (accessed on 16.12.2018).

Programma rodstvennyh narodov Estonii (2010). [The program of the related to Estonia peoples]. Sajt NDO «Uchrezhdenie Fenno-Ugria». URL: http://jabadaba.eki.ee/public/buklet-hp.pdf (data obrashcheniya: 16.12.2018).

Rīcības plāns. Par sadarbību ar Latvijas diasporu 2015.-2017. Gadam (2014). [Action plan. About cooperation with the Latvian diaspora in 2015-2017]. URL: http://www.mfa.gov.lv/data/file/AMPlans_150714_Diaspora.662.pdf (accessed on 16.12.2018).

Tammaru T., Kumer-Haukanõmm K., Anniste K. (2010). The Formation and Development of the Estonian Diaspora. Journal of Ethnic and Migration Studies. Vol. 36, No. 7, August 2010. Pp. 1157-1174.

Užsienio lietuvių apklausa apie jų būklę ir poreikius. $2017 \mathrm{~m}$. spalis - lapkritis (2017). [Survey of foreign Lithuanians about their condition and needs. 2017, October-November]. Vilmorus. URL: https://www.urm.lt/uploads/default/documents/2017\%20m_\%20u\%C5\%BEsienio\%20lietuvi\%C5\%B3\%20ap klausa.pdf_(accessed on 16.12.2018).

\section{Contemporary Challenges to Diaspora Policies of the Baltic States}

Author. Vorotnikov V., Candidate of Sciences (History), Research fellow of Department of Central and Eastern European studies, Institute of Europe RAS; Research Fellow, Centre for European Studies, Institute for International Studies, MGIMO-University; Associate Professor, Department for European and American Studies, MGIMO-University; Address: 11-3, Mokhovaya str., Moscow, Russia, 125009; E-mail: vorotnikov.vladislav@gmail.com.

Abstract. The article is devoted to the modern policies of the Baltic states towards their diasporas. Despite the small population, the foreign diasporas of emigrants from these countries (primarily ethnic Latvians, Lithuanians and Estonians) are numerous and continue to influence both the internal socio-economic and political processes in the Baltic states, and in host countries, e.g. the USA). On the basis of a comparative analysis, the article examines the current situation of the Baltic diasporas, as well as the goals and political practices of the state policies of Latvia, Lithuania and Estonia in maintaining contacts with diasporas and repatriation. The latter is extremely important for the Baltic countries concerning negative trends in the demographic situation (not decreasing rates of emigration, reduction in the birth rate, aging of population). However, the neoliberal economic policy of the governments, which does not create favorable conditions for socio-economic development and growth of living standards, makes the diaspora policies of the Baltic states ineffective.

Key words. Diasporas, diaspora policy, Baltic states, Latvia, Lithuania, Estonia.

DOI: http://dx.doi.org/10.15211/soveurope72018137151 